\title{
PHILOLOGY: INTERTEXTUALITY CHAIRIL ANWAR AND SHINDUNATA
}

Rohib Adrianto Sangia

\begin{abstract}
The term intertextual is generally understood as the inter-relationship of the text with other text. Each text is a mosaic of quotations and every text is absorption and transformation from other texts. Text made of quotation, absorption, and transformation of other texts. As the author writes, the author will take the components of another text as a basis for the creation of his work. All was prepared and given to the adjustment of color, and if necessary, may be added in order to become a complete work. Intertextual approach emphasizes the notion that a literary text is seen as writing or graft insertion in the framework of other literary texts, such as tradition, literary genres, parody, reference or citation.
\end{abstract}

Keywords: Philology, Intertextual, Chairil Anwar, Shindunata

\section{INTRODUCTION}

Each author creates literary works will be different from that of other authors. Such differences may lie in the type of text, the methods used, the emergence of the creative process, and how to express what is inside of the author. However, the process of creating different works of literature by some authors did not rule out the similarity between the results of these texts. It is also because there are some authors who create literature based or based on the literary works of other authors. This is also intertextual, intertextual will create stories contained similarities between literary works that one with another literary work (Efendi, 2012: 2).

Intertextual study is intended as a study of a number of texts or literary text, which is thought to have certain forms of association, such as suggest a link between the intrinsic elements such as ideas, ideas, events, plot, characterization, style of language, and so on, the texts studied (Shuart-Faris and Bloome, 2004: 18-20). The problem of the existence of Intertextual has relations with the author's intention and reader interpretation. Intertextual study departs from the assumption that at any time the work was written, it was not possible cultural emptiness born of the situation. Literary works written much later usually based on the works of others who have been there before, either directly or indirectly, either by forwarding or deviate conventions, rejecting, distorting the essence.

Intertextuality relationship between a literary works with other literature in the works of contemporary Indonesian literature occurred much in recent years. This paper is trying to reveal the intertextual relationship between the works of Chairil Anwar's Aku with Sindhunata's Kutukan Asu which has 50 years range to obtain and understand the full meaning of a poem to be seen this intertextual relationship. Intertextual relationship shows the similarities and contradictions in terms of aesthetic concepts and opposite view of life. 


\section{SAUSSURE, BAKHTIN AND KRISTEVA}

Foundation stone of semiotic theory there are two people that Ferdinand de Saussure and Charles Sanders Pierce. Semiotics is the science or analytical methods to assess the sign (Allen, 2000: 218). The sign is something that represents something else that can be experiences, thoughts, feelings, ideas, etc. The development of semiotic theory until today can be divided into two types, namely semiotic communication theory that emphasizes the production of signs and semiotic significance or giving emphasis on understanding the meaning of a sign.

This theory is actually related to the development of linguistic theory in general. Language as a system of signs, according to Saussure has two inseparable elements which they are the signifier and the signified, signifiant and signifie, or signifier and signified (Ray, 2004: 212-213). The fact that language is a system means that it is composed of a number of elements, and elements that interact on a regular basis and function in accordance with the rules, so it can be used to communicate. Semiotic study of literature, thus, can begin by examining linguistic-level using the level as in the study of linguistics. Language as an aspect of the material or equipment in the literature, another case with, for example, paint in painting, has had a particular meaning in accordance with the concept of community conventions wearer

Bakhtin is a Russian literary expert, who introduced the concept dialogism. Dialogism according to Bakhtin is a core element of all languages, in the form of linguistic interaction of each individual or group in a particular social context. Another party or otherness in language is the most important concept of dialogism Bakhtin (Allen, 2000: 20-21).

Bakhtin examines many literary works from various periods. From his research he discovered the existence of the principles dialogists and monologists departing from the relationship between literature and society. The several concepts that was introduced in order to define dialogism are polyphony, heteroglossia, double-voiced discourse and hybridization (Allen, 2000: 22). Polyphony demonstrates and celebrates the dialogic nature of society by presenting a vision of human society dominated by the dialogue and play between voices and utterances. Heteroglossia refers to the conflict between "centripetal" and "centrifugal", "official" and "unofficial" discourses within the same national language. The term also has a smaller-scale application that every utterance contains within it the trace of other utterances, both in the past and in the future. Double-voiced discourse is another's speech in another's language, which means that there are two voices, two meanings and two expressions. Double-voiced discourse helps to speak indirectly, conditionally, in a refracted way, to introduce more expressive intentions and to develop idea of heteroglossia. Finally, Hybridization is a blend of two social languages inside the bounds of a single utterance, an encounter, within the field of an utterance, between two different linguistic consciousness, separated from one another by an period, by social difference or by some other factor (Bakhtin and Holquist, 1981: 358).

Intertextuality theory was originally introduced by Julia Kristeva (Culler, 2001: 114) a researcher from France revealed that the amount of knowledge that can make a text that has meaning, or intertextuality is inevitable, because each text dependent, absorb, or change form of 
the previous text. Kristeva (1980: 36-37) explained that text is one permutation from other texts. Intertextual view the text is in the space of the specified text, the text is a variety of speech acts, the text is taken from other texts, and text are overlapping and mutually neutralize each other.

Text is praxis as well productivity, means that the text never displays a clear and stable meaning, since it represents a dialogical community conflicts through the meanings of words. So intertextuality not only see a text through the emergence of social text, but also the continuation of its existence in society and history. As a consequence of this view, the structure and meaning of the text can no longer be considered merely as a specific feature of the text is concerned. According to Kristeva (1980: 37), texts or parts of texts is Ideologeme. Fredric Jameson defines this as 'the smallest intelligible unit of the essentially antagonistic collective discourses of social classes (Hawthorn, 1992: 80).

\section{INTERTEXT ANALYSIS}

$A k u$ was probably the most famous work and is also one of the most prominent poems of Angkatan 45. Aku have the theme of rebellion from all forms of oppression. The author would like to "hidup seribu tahun lagi", but he realizes the limitations of his age, and when death arrives, he does not want anyone to wail. Aku was read firstly at the Cultural Center Jakarta in July 1943, and then printed in Pemandangan with the title of Semangat (Eneste, 1995: 27-28). According to the documentary Indonesian literature, HB Jassin, It was aimed to avoid censorship and to further promote freedom of movement. Aku has gone on to become the most famous poem of Chairil Anwar.

Kutukan Asu can be said to take inspiration from the poetry Chairil Anwar's Aku. Asu names and properties are usually synonymous with negativity because besides identified with nature and often lick name asu or dogs used as swear words. Furthermore, this poem started to give the story about dogs in several moments in Javanese mythology. It starts with words "su" as part of "Asu" compares with some great men, story about Dogs in Sangkuriang folktale, story about the friendship of human and dog, the course of Menak Jingga to have appearance of dog.

By looking at "aku", it is not unconscious selected by the author. There is an interesting matter of "Aku", Position of aku at the time after of independence in Indonesia, not enough as a slang of the time, because the word aku visibly reflected arrogance even ego centrism, but this is where the power of a poem $A k u$ can survive throughout the ages, between entities and between countries. Even the title of this poem there would be irreplaceable in the history of modern literature, "aku" still able to attract many people all the time.

The sign "aku" is sometimes informally, sometimes while edema was hitting the chest and left the impression demands in all directions, both the speaker and the person in talking to. In contrast to the word "saya" that is closer as a first person pronoun. "Aku" is clearly different from the grip Malay mother tongue which it is the environment of the place of Anwar origin. Another option maybe it can be substitute with generally prefer hamba, abdi, kaula, dalem, etc. in order to respect in Java socio-structure and then use mas, mbak, tuan, bapak, ibu, nyonya, etc. to the 
second person point of view within the manner and respect. Those excuse before have given the place to Saussure's theory that "aku" is selected as syntagmatic axis of language.

The sign "aku" may influence to "asu". It is believed that they are the character of the author during in the works. "Asu" basically have related sound with "aku". The language tradition of Anwar, who lived in the beginning of independence years, gives spaces to burn the freedom spirit of the people who missed the real freedom. Rises in the rebellion community makes Anwar's language attitude and habit feels more powerful. It is totally different with "asu", which the author was lived in orde baru regime, that the culture of Javanese was developed became the national culture, since the many national development was centered and held most Javanese people, and continued to reformation era when the national economic was going worse and left many destructions.

Another interesting of "asu" is the author was trying to explain the position of the sign "su" in the context of human being and the animals in Javanese culture as the language concept. This explanation implicitly gives the clear understanding the difference "signified" as concept and "signifier" - in here "su" - as the sound-image. Both "aku" and "asu" are the symbols that describe many things as the idea transfer from the author to the reader, but indeed with many drills of understanding.

The content of "aku" can be seems as monophony works and "kutukan asu" is polyphony. The relation both of the poems are Sindhunata makes the poem wider not only from the mosaic from Chairil. The subject "asu" was narrated in the poem with many point of view and results many voices. The first point of view clearly stated in "aku ini asu." The first person pronoun gives the short introducing to the reader before going in to the core of poem.

Later in the "kutukan asu", many figures that introduced by the author as the manifestation of the dog. It gives many point of view or many meanings and sounds from "asu". There are many role of "asu" in Sindhunata poems. It became home pet as in "aku ini hanya kewan omahan". Other occasion is "asu" as the incarnation of the Javanese mythology character as the beast creature because was cursed by Goddess. Other case, the subject "asu" is dreamed become a man with negative behavior as the opinion. The word "asu" in advanced is transformed with the context of social life of the author, that can be found in "Tiba-tibalah perintah negara: Semua anjing kampung harus dimusnahkan dalam tiga hari"

Another aspect of Bakhtin concept is heteroglossia. The case of heteroglossia is found in Sindhunata works as the respon of Chairil's. Sindhunata was represented Kutukan Asu with his own language, thus gives the concepts of heteroglossia and hybridization in it. In Kutukan Asu clears mentioned many dialects of Ngoko Javanese, the Sanskrit, and ordinary Indonesian. It is surely gives the clear description about the conflict of awareness inside the work.

The indication of heteroglossia can be found in "Aku ini binatang Jalang" dan "Aku ini kewan omahan". Other things are the word "asu" is transformed originally from "Binatang Jalang", and it is expanded to "asu", "anjing", and "sona" by Sindhunata. The hybridization is used by Sindhunata in Kutukan Asu is appear many times. It is related with example of heteroglossia 
before. The several different linguistics consciousness is synthesized by Sindhunata. The different linguistics consciousness which clear be seen for example "di-Erwe". In Manado dishes, dog meat is known as the "RW" (abbreviation of "rintek wuuk" derived from Tombulu or Minahasa language means fuzz). So "di-Erwe" is the combination words from such difference linguistics system became used to make the stressing and extended information in such unique ways.

The double-voiced discourse can be looked at word "aku" and "asu" sometimes, "asu" in many place in Sindhunata works become the other subject not the author himself. In "lebih baik jadi asu daripada jadi manusia", shows that asu in here represents to the general dog and do not refer to the author as the subject. Double-voiced discourse of "asu" from Sindhunata might be manifestation of "binatang jalang" from Anwar.

After reading Anwar's Aku which shorter than Sindhunata's Kutukan Asu, it can be concluded that $A k u$ is a part mosaic in bigger part of Kutukan Asu. But the most thing that some words of Anwar, for example, "aku”, "binatang jalang", "peluru”, "merajang menerjang", "hidup seibu tahun lagi" is used by Sindhunata consistently, but many of them is served with paradox of real life which are different between two era. The same words but they are in different Ideologeme between those two works piece by piece are different.

\section{CONCLUSION}

The process of creating works of literature by some authors did not rule out the similarity between the results of these texts. It is also because there are some authors who create literature based or based on the literary works of other authors. This is also intertextual, that create stories contained relations between literary works that one with another literary work.

The term intertextual is generally understood as the inter-relationship of the text with other text. Each text is a mosaic of quotations and every text is absorption and transformation from other texts. Text made of quotation, absorption, and transformation of other texts. As the author writes, the author will take the components of another text as a basis for the creation of his work. All was prepared and given to the adjustment of color, and if necessary, may be added in order to become a complete work. Intertextual approach emphasizes the notion that a literary text is seen as writing or graft insertion in the framework of other literary texts, such as tradition, literary genres, parody, reference or citation.

The analysis exposes the intertextual relationship between the works of Chairil Anwar's Aku with Sindhunata's Kutukan Asu with some aspect from theories of Ferdinand Saussure about semiotic relationship, the concepts of dialogism from Bakhtin and the Ideologeme of Kristeva. Finally, it is no doubt that Kutukan Asu is a big mosaic from many literature, from ancient until contemporary literary work by using $A k u$ as the main frame in synthesizing the word "asu". 


\section{REFERENCES}

Allen, Graham. 2000. Intertextuality. New York: Routledge.

Bakhtin, M. M., and Holquist, Michael. 1981. The dialogic imagination : four essays. Austin: University of Texas Press.

Culler, Jonathan D. 2001. The pursuit of signs : semiotics, literature, deconstruction (Augmented ed.). London: Routledge.

Efendi, Arapa. 2012. The Implementation of Intertextuality Approach to Develop Students' Critical Thinking in Understanding Literature. LEKSIKA Vol. 6 No. 1.

Eneste, Pamusuk. 1995. Mengenal Chairil Anwar. Jakarta: Obor.

Hawthorn, Jeremy. 1992. A concise glossary of contemporary literary theory. New York: Routledge.

Kristeva, Julia. 1980. Desire in language : a semiotic approach to literature and art. New York: Columbia University Press.

Ray, Mohit Kumar. 2004. Studies in ELT, linguistics and applied linguistics. New Delhi: Atlantic Publishers \& Distributors.

Shuart-Faris, N., and Bloome, D. 2004. Uses of Intertextuality in Classroom and Educational Research. Greenwich: Information Age Pub. 